\title{
Report of the Subcommittee on Numerical Taxonomy
}

The minutes of the Mexico 1970 meeting of the Subcommittee have been published (as a Report, Int. J. Syst. Bacteriol. 21:156).

A report on computer-assisted methods for identification of microorganisms is being prepared by Drs. H. Gyllenberg, S. Lapage, L. R. Hill, and M. Krichevsky.

The Subcommittee met at the time of the Jerusalem Congress and considered the matters of test reproducibility, standardization of testing methods, and "standard strains." Prof. Sneath presented a document on test reproducibility (see also his contribution to 1st International Congress for Bacteriology, Session $\mathrm{H}$, Taxonomy, and Congress Abstracts, Volume 11, p. 87) raising two main questions: (i) what is the true degree of discrepancy between laboratories under routine conditions, and (ii) should guidance be given on how to set up testing schemes to investigate such discrepancies? The document emphasizes the need for blind trials, to publish results even if unwelcome, to maintain anonymity of participants, and to give exact specification of testing methods and scoring methods. The Subcommittee on Numerical Taxonomy is willing to help other subcommittees with problems within our field.

The compilation of a handbook of testing methods was deferred until other subcommittees have drawn up their respective Minimum Descriptions for Taxa. It is hoped that these Descriptions will give full details of testing methods.

The Subcommittee endorses the principle of workshops or training courses in numerical taxonomy.

The present membership of the Subcommittee is as follows: H. G. Gyllenberg (Finland, Chairman), R. R. Colwell (U.S.A., Secretary), J. DeLey (Belgium), J. R. Hill (U.K.), O. Lysenko (Czechoslovakia), L. G. Silvestri (Italy), V. B. D. Skerman (Australia), P. H. A. Sneath (U. K.), M. Véron (France).

R. R. Colwell, Secretary

\section{Report of the Subcommittee on Listeria and Related Organisms}

In April 1973 the Executive Board of the ICSB established a Subcommittee to revise the taxonomy of Listeria and related bacteria. Dr. $\mathrm{H}$. Welshimer was appointed to act pro tem as Chairman and Dr. Dorothy Jones to act pro tem as Secretary until the first formal meeting of the Subcommittee.

The full foundation membership of the Subcommittee is as follows: Dr. J. DonkerVoet, Burg. Haefkensstraat 1, Houten (U), Netherlands; Prof. Dr. N. Ivanov, Veterinary Institute of Infectious and Parasitic Diseases, Cul. P. Slaveikov 15-a, Soffia -VI, Bulgaria; Dr. D. Jones (Secretary pro tem), MRC Microbial Systematics Unit, University of Leicester, University Road, Leicester, England; Prof. Dr. Ortel, Institut für Medizinische Mikrobiologie, Universität Halle/S., Halle/Saale, Leninallee 6, German Democratic Republic; Dr. B. Ravlovich, Institute of Microbiology, University of Pecs, Szigeti ut. 30, Pecs. Hungary; Prof. Dr. H. P. R. Seeliger, Institut für Hygiene und Mikro- biologie, Josef-Schneider-Str. 2, 87 Würzburg, Federal Republic of Germany; Dr. H. Welshimer (Chairman pro tem), Department of Microbiology, University of Virginia, Medical School, Richmond, Virginia 23219, U.S.A.; Dr. M. Woodbine, Department of Applied Biochemistry and Nutrition, School of Agriculture, Sutton Bonnington, Loughborough, LE1 5RD, England.

No formal meeting was held in Jerusalem in September 1973 but informal talks were held between those members present. It was generally agreed that the date and place of the first formal meeting should be at Sutton Bonnington, England at some time during the VIth International Symposium of Problems of Listeriosis, 23-27 September 1974.

Dorothy Jones agreed to draw up an agenda for the first formal meeting after corresponding with the other members.

Dorothy Jones, Secretary pro tem 